\title{
Image deblurring process based on separable restoration methods
}

\section{P. Stanimirović, I. Stojanović, S. Chountasis \& D. Pappas}

\section{Computational and Applied Mathematics}

ISSN 0101-8205

Volume 33

Number 2

Comp. Appl. Math. (2014) 33:301-323

DOI 10.1007/s40314-013-0062-2
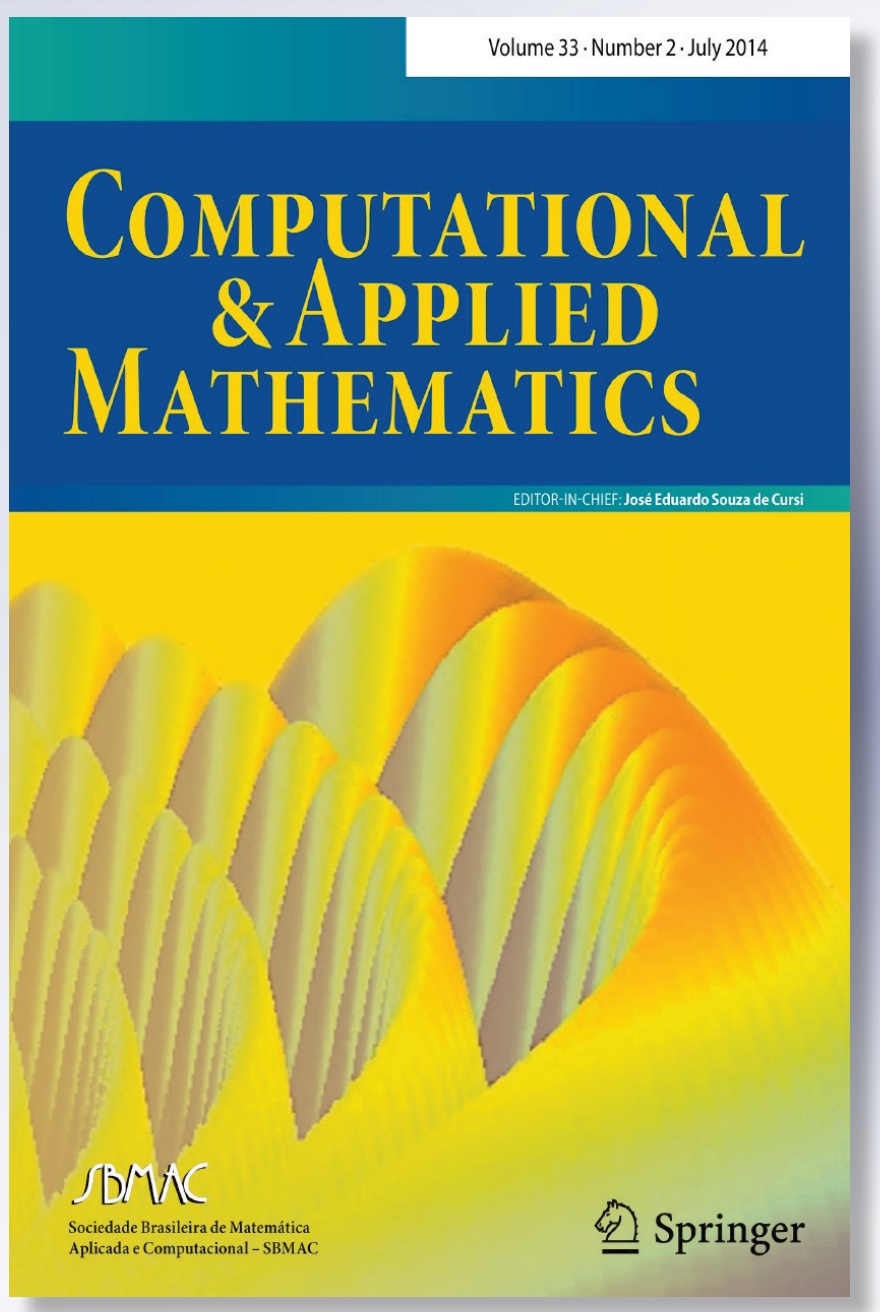

Springer 